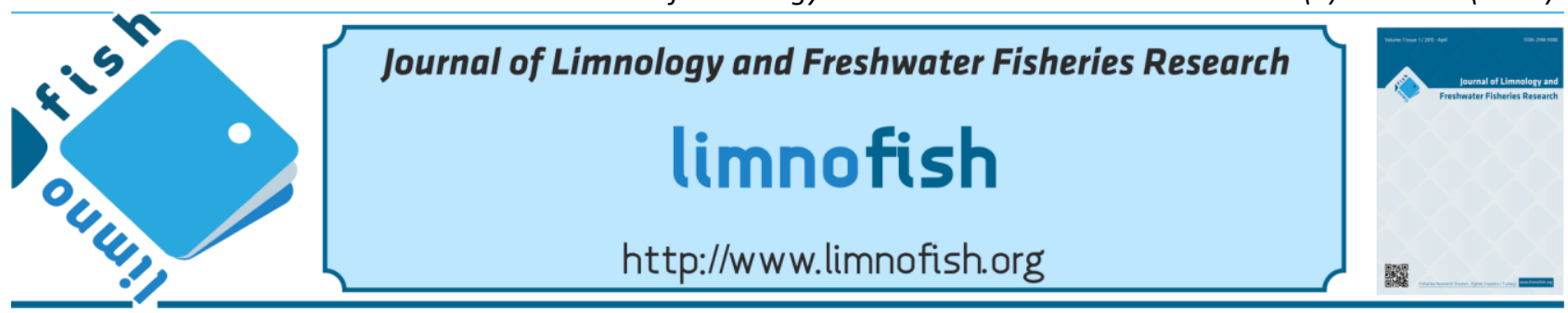

\title{
Distribution of Cladocera Species in Different Waters of Turkey
}

\author{
Ahmet BOZKURT*', Mevlüt AKTAŞ \\ Iskenderun Technical University Marine Sciences and Technology Faculty, 31200, Iskenderun, Hatay, Turkey
}

\section{A B STRACT}

Species diversity and distribution of Cladocera collected from river, dam lake, lake, marshes and well, in different regions of Turkey have been reported. Fortyfour samples collected from 31 different localities contained 37 species belonging to six families. Chydoridae was the most species rich family with 18 species followed by Daphniidae with 11 species. Bosmina coregoni, a rare species for Turkey inland waters, is a new record for Mediterranean region of Turkey.

Keywords: Cladocera, freshwater, Bosmina coregoni

\section{ARTICLE INFO}

\section{RESEARCH ARTICLE}

Received : 25.03.2016

Revised : : 16.07.2016

Accepted :08.09.2016

Published : 23.12.2016

DOI: $10.17216 /$ LimnoFish.279722

* CORRESPONDING AUTHOR

ahmetbozkurt1966@hotmail.com

Tel : +903266141693

Fax: +903266141877

\begin{abstract}
Türkiye'nin Farklı Sularında Kladoser Türlerinin Dağılımı
Öz: Türkiye'nin farklı bölgelerindeki nehir, baraj, göl, sazlık ve kuyulardan, farklı dönemlerde toplanan Kladoser türlerinin çeşitliliği ve dağılımı belirlenmiştir. 31 farklı lokaliteden toplanan 44 örnekten, 6 familyaya ait 37 tür belirlenmiştir. Chydoridae 18 türle en çok tür barındıran familya olmuş, bunu 11 türle Daphnidae takip etmiştir. Türkiye içsularında nadir bulunan Bosmina coregoni, Türkiye'nin Akdeniz Bölgesi için yeni kayıttır.
\end{abstract}

Anahtar kelimeler: Cladocera, tatlisu, Bosmina coregoni

How to Cite

Bozkurt A, Aktaş M. 2016. Distribution of Cladocera species in different waters of Turkey. LimnoFish. 2(3):137-143. doi: 10.17216/LimnoFish.279722

\section{Introduction}

The Cladocera species, which create an important proportion of zooplanktonic organisms, are found in almost all kind of aquatic habitats such as rivers, lakes, ponds, streams, wetlands and other bodies of water. Cladocerans are known as essential components of the food chain for the freshwater ecosystem, because they are the most important grazers of phytoplankton, and thus herbaceous material is diverted to animal material through these zooplankton. For this reason, these species are biological indicators of the water systems where they are found (Güher 2000). On the other hand, living cladoceran communities and their fossil remains preserved in lake sediments reflect their aquatic habitat in similar ways (Kattel et al. 2006; Davidson et al. 2007).
Cladocerans are small-sized $(0.2-6 \mathrm{~mm})$ except Leptodora kindtii, branchiopod crustaceans, inhabiting pelagic, littoral, and benthic zones. Four cladoceran orders are recognised (Frey 1987): Anomopoda, Ctenopoda, Onychopoda, and the monotypic Haplopoda. The trunk and appendages of most cladocerans (Anomopoda and Ctenopoda) are enclosed in a bivalved carapace. Tagmosis of the body is mostly obscure, and a single eye and ocellus are usually present. Cladocerans are important components of the fauna of fresh waters; they are particularly significant in the food web of stagnant waters.

Most species are filter-feeders; onychopods and haplopods are predatory. They usually reproduce by cyclical parthenogenesis, and populations are mostly dominated by females. Sexual 
dimorphism is normally rather distinct. Sexually produced diapausing eggs are resistant to desiccation and other unfavourable conditions, and may even survive passage through the digestive track of birds (Figuerola and Green 2002); thus, they are important propagules for passive dispersal (Forro et al. 2008).

A number of studies of Cladocera fauna of Turkey have been previously conducted by Gündüz (1991, 1997); Temel (1996); Göksu et al. (1997); Güher (1999, 2000, 2002, 2014); Tellioğlu and Şen (2001); Ustaoğlu et al (2001 a, b); Bekleyen (2003, 2006); Ustaoğlu (2004); Tellioğlu and Yılmaztürk (2005); Aladağ et al (2006); Saler and Arslan (2007). Alper et al (2007); Dirican and Musul (2008); Bozkurt et al (2009); Saler and İpek (2009); Yıldız et al (2010); Günsel and Emir Akbulut (2012); Kaya et al (2012); Apaydın Yağcı (2013); Saler and
Alış (2014); Apaydın Yağcı et al (2015); Güher and Çolak (2015); Gürel and Saler (2015).

\section{Materials and Methods}

The samples of cladocerans were collected from 31 different freshwater localities using $60 \mu \mathrm{m}$ plankton net. The samples were fixed with $4 \%$ formaldehyde. An Olympus CH40 microscope and a camera were used for drawings of the species. Measurements were made with a Zeiss microscope and camera. Body measurements of Bosmina coregoni specimens were made from head to end of mucro, and carapace height. The species were identified with the aid of Scourfield and Harding (1966), Smirnov (1974), Negrea (1983), Korinek (1987) and Pennak (1989). All sampling points are freshwater except Titreyen Lake (Side, Antalya), slightly brackish water in the property. The sampling localities and sampling dates are given in Table 1.

Table 1. Sampling localities and sampling dates.

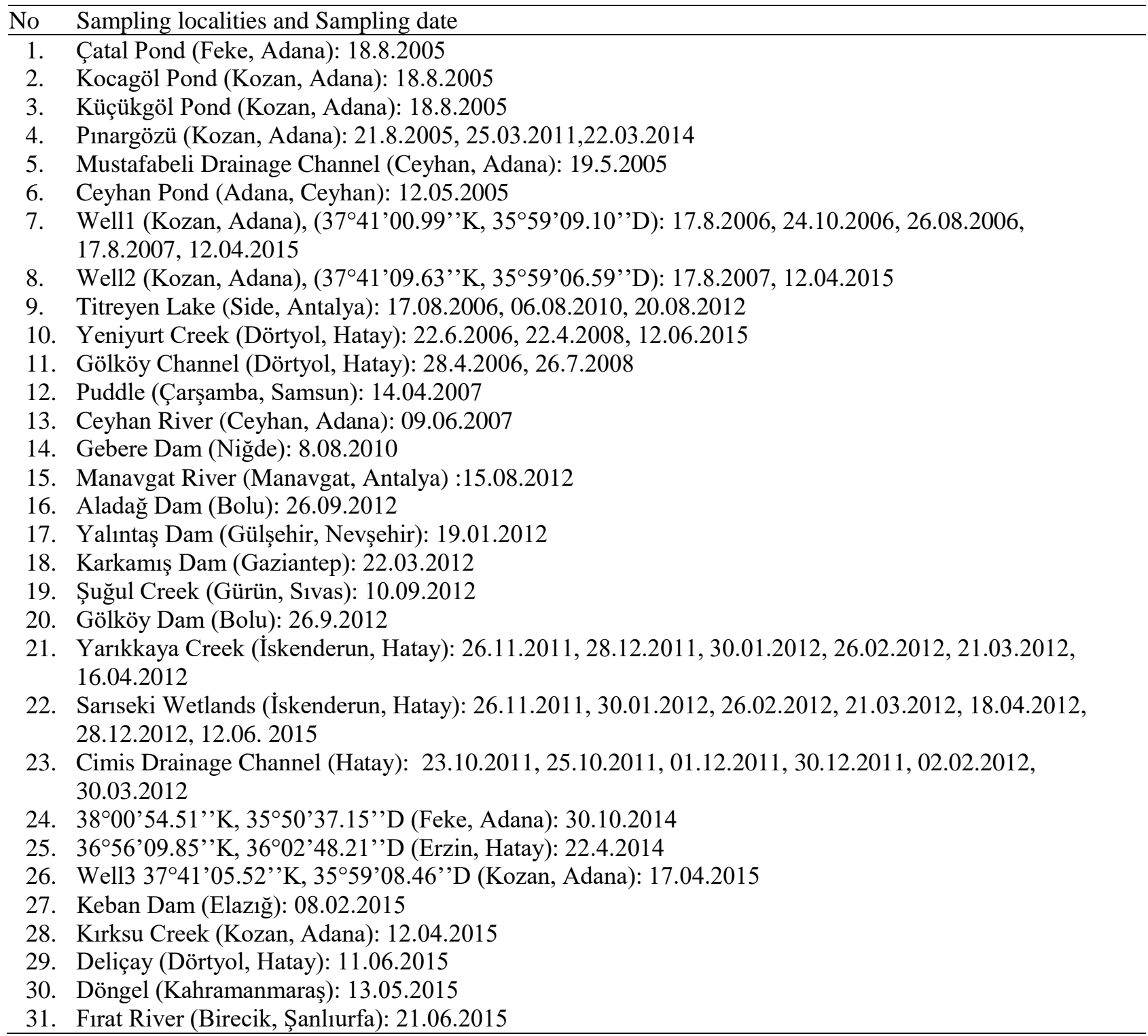




\section{Results}

The samples collected from 31 different localities that consists of lakes, dam lakes, streams, ponds, wells and springs. A total of 37 species of Cladocera were determined. Detected six families Chydoridae was the most species rich family with 18 species followed by Daphniidae with 11 species. Moinidae had the least species followed by Bosminidae and Sididae. The species and their localities are as Table 2.

Table 2. Detected species and localities.

\begin{tabular}{|c|c|}
\hline Species & Localities \\
\hline \multicolumn{2}{|l|}{ Family: Bosminidae } \\
\hline Bosmina longirostris (Müller, 1776) & $5,10,11,12,13,14,16,17,21,22,23,27,28,31$ \\
\hline Bosmina coregoni Baird, 1857 & 10,18 \\
\hline \multicolumn{2}{|l|}{ Family: Daphniidae } \\
\hline Ceriodaphnia pulchella Sars, 1862 & $10,19,11,16,23,31$ \\
\hline Ceriodaphnia quadrangula (Müller, 1785) & 28 \\
\hline Daphnia ambigua Scourfield, 1947 & 16 \\
\hline Daphnia carinata King, 1852 & $1,2,3$ \\
\hline Daphnia cucullata Sars 1862 & 18 \\
\hline Daphnia galeata Sars, 1864 & 27 \\
\hline Daphnia longispina (Müller, 1776) & $5,10,16,18$ \\
\hline Daphnia magna Straus, 1820 & 23 \\
\hline Daphnia pulicaria Forbes, 1893 & 12 \\
\hline Scapholeberis kingi Sars, 1888 & 25 \\
\hline Simocephalus vetulus (Müller, 1776) & $5,12,19,29,31$ \\
\hline \multicolumn{2}{|l|}{ Family: Sididae } \\
\hline Diaphanosoma birgei Korinek, 1981 & $18,19,27$ \\
\hline Diaphanosoma brachyurum (Liévin, 1848) & 6 \\
\hline \multicolumn{2}{|l|}{ Family: Moinidae } \\
\hline Moina micrura (Jurine, 1820) & $1,6,9,13,16,23$ \\
\hline \multicolumn{2}{|l|}{ Family: Chydoridae } \\
\hline Acroperus angustatus Sars 1863 & 19 \\
\hline Alona costata Sars, 1862 & 22,23 \\
\hline Alona guttata Sars, 1862 & $5,9,15,19,20,31$ \\
\hline Coronatella rectangula (Sars, 1862) & $2,4,9,10,11,13,14,19,20,21,22,23,27$ \\
\hline Alona quadrangularis (Müller, 1776) & 4,30 \\
\hline Alonella exigua (Lilljeborg, 1853) & 11 \\
\hline Alonella excisa (Fischer, 1854) & $10,20,22,23$ \\
\hline Biapertura affinis (Leydig 1860) & 19 \\
\hline Camptocercus uncinatus Smirnov, 1971 & $9,10,20,22,31$ \\
\hline Chydorus sphaericus (Müller, 1776) & $4,10,11,12,14,19,20,21,22,23,24,25,26,31$ \\
\hline Disparalona rostrata $($ Koch, 1841$)$ & 23 \\
\hline Dunhevedia crassa King, 1853 & 9 \\
\hline Eurycercus lamellatus (Müller, 1776) & 31 \\
\hline Graptoleberis testudinaria (Fischer, 1848) & 18,31 \\
\hline Leydigia acanthocercoides (Fischer, 1854) & 23,27 \\
\hline Pleuroxus aduncus (Jurine, 1820) & $7,8,11,12,14,19,20,23,26$ \\
\hline Picripleuroxus laevis (Sars, 1862) & $10,20,21,22,31$ \\
\hline Oxyurella tenucaudis (Sars, 1862) & $4,11,20$ \\
\hline \multicolumn{2}{|l|}{ Family: Macrothricidae } \\
\hline Ilyocryptus sordidus (Liévin, 1848) & 23,27 \\
\hline Macrothrix laticornis (Jurine, 1820) & 13,23 \\
\hline Macrothrix groenlandica Lilljeborg 1900 & 17 \\
\hline
\end{tabular}


Altough Bosminidae family has approximately fourty species in the world, So far the only 2 species, Bosmina longirostris (Müller, 1776) and B. coregoni Baird, 1857 have been reported from Turkish inland waters.

It was recorded that the most found species Bosmina longirostris and Chydorus sphaericus (Müller, 1776) in 14 localities followed by Coronatella rectangula (Sars, 1862) in 13 localities and Pleuroxus aduncus (Jurine, 1820) in 9 localities. The species found only 1 localities was Daphnia ambigua Scourfield, 1947, Daphnia cucullata Sars 1862, Daphnia galeata Sars, 1864, Daphnia magna Straus, 1820, Daphnia pulicaria Forbes, 1893, Scapholeberis kingi Sars, 1888, Diaphanosoma brachyurum (Liévin, 1848), Acroperus angustatus Sars 1863, Alonella exigua (Lilljeborg, 1853), Biapertura affinis (Leydig 1860), Disparalona rostrata (Koch, 1841), Dunhevedia crassa King, 1853, Eurycercus lamellatus (Müller, 1776) and Macrothrix groenlandica Lilljeborg 1900 (Table 2).

Body of female Bosmina coregoni short and wide (Figure 1A), with length 0.54-0.90 $\mathrm{mm}$. Carapace sculptured with longitudinal lines on the head shield. Highness of valves about 1.5 times that of body. Valves with evenly curved dorsal edge. Ventral edge of valve slightly convex, with a series of stout setae, the bases of which are located on its internal surface. Posterior edge practically straight, about 2.5 times shorter than largest length of valve. Mucro (Figure 1B) spiniform, relatively short, its basis considerably extended. On its tip, two concentric series of pointed tubercles. Frontal edge of head convex, rostrum short and blunt. Antennules rather short, slightly folded, posteriorly directed, with powerful basis and pointed tips. Frontal sensory setae relatively long. Frontal head pore located between these setae, the median pore on the frontalmost point of the head (Figures 1C). Second antennae with powerful basal part, with cross series of denticles and short branches, and also girdled by similar rows. Lateral head pore located near articulation of mandible. Eye of female roundish, large, located closer to basis of second antenna than to frontal edge of head. Postabdomen of adult female strongly compressed, lamelliform, its width equal along all its length (Figure 1Da). Distal edge nearly directly truncated. Anus opening on this edge as a long, wide, vertical slit.
A conical projection with two long postabdominal claws on ventral surface of postabdomen (Figure 1Db). A row of rather large denticles present on their basal part, continued in a group of 3-5 small-sized denticles on base of claws (Figure 1Db). Several rows of thin delicate setae located on internal and external surface of claws. Back and dorsal edges of postabdomen covered by cross interrupted series of relatively long thin setules (Figure 1Dc). Such series present near basis of postabdomen on the plate, situated over the post-abdominal setae.

Thirty female specimens of $B$. coregoni examined from Yeniyurt Creek (Dörtyol, Hatay) and Karkamış Dam Lake (Gaziantep). Length of body: 0.54-0.90 mm, Heigth of body: 0.34-0.64 mm.

\section{Discussion}

In this study a total of 31 water bodies, river, dam lake, lake, marshes, pond and well were sampled and a total of 37 cladocer species were identified, with 18 Chydoridae species, 11 Daphnidae species, 3 Macrothricidae species, 2 Bosminidae and Sididae species, 1 Moinidae species (Table 2). The species appear to contain typical tropical as well as cosmopolitan and littoral inhabiting (Ryding and Rast 1989). They were widespread in Turkey and worldwide because they were found almost all regions of Turkey (Güher 2000; Alper et al. 2007; Dirican and Musul 2008; Bozkurt et al. 2009; Saler and İpek 2009; Y1ld1z et al. 2010; Günsel and (Emir) Akbulut 2012; Kaya et al. 2012; Apaydın Yağcı 2013; Güher 2014; Saler and Alış 2014; Apaydın Yağc1 et al. 2015; Güher and Çolak 2015; Ustaoğlu 2015; Gürel and Saler 2015).

B. coregoni, rare species inland waters of Turkey, was reported first time by Güher and Kirgiz (1989) from Edirne province inland waters, and later it was reported by Özbay and Kılınç (2008) from Aktaş Lake (Ardahan).

It was reported third times from Turkey, B. coregoni is widespread, small-bodied, filter-feeding cladocerans common in the open-water areas of both the littoral and pelagic zones of oligotrophic and mesotrophic freshwater lakes and ponds, and distributed in the northern and middle holarctic (DeMott and Kerfoot 1982).

The presence and distribution of the species in the study even holarctic B. coregoni is quite closely related to the ecological characteristics of the species, and all species in the study are widespread. 


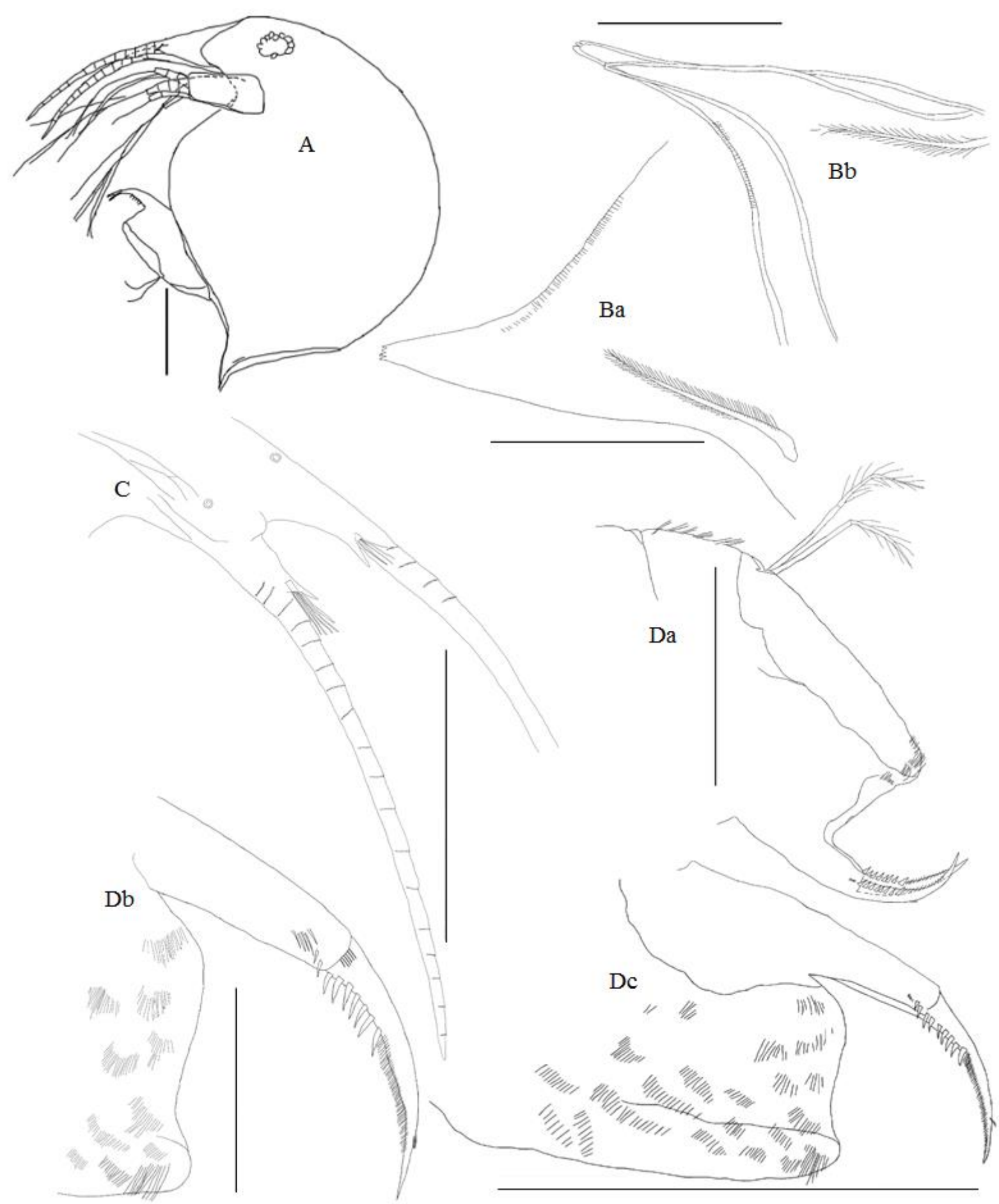

Figure 1. Full body and body parts of female Bosmina coregoni. (A) Female body, bar $250 \mu$; (Ba, Bb) Mucro, bar 60 $\mu$; (C) Antenna I and head pores, bar $250 \mu$; (Da) Postabdomen of adult female, bar $250 \mu$; (Db) Claws, bar $60 \mu$; (Dc) Setules on postabdomen, bar $250 \mu$.

\section{References}

Aladağ AT, Erdem C, Karaytuğ S. 2006. Cladocera and Copepoda (Crustacea) fauna of Çatalan Dam Lake (Adana, Turkey). Ege J Fish Aqua Sci. 23(3-4):427-428

Alper A, Çelebi E, Çam H, Karaytuğ S. 2007. Cladocera and Copepoda (Crustacea) Fauna of İkizcetepeler Dam Lake (Balıkesir, Turkey). TrJFAS. 7(1):71-73.
Apaydın Yağcı M, Yılmaz S, Yazıcı̆̆glu O, Polat N. 2015. The zooplankton composition of Lake Ladik (Samsun, Turkey). Turk J Zool. 39(4):652-659. doi: 10.3906/zoo-1312-54

Apaydın Yağcı M. 2013. Seasonal zooplankton community variation in Karataş Lake, Turkey. Iran J Fish Sci. 12(2):265-276. 
Bekleyen A. 2006. Cladocera and Copepoda fauna (Crustacea) of Devegeçidi Dam Lake (Diyarbakır). Ege J Fish Aqua Sci. 23(3-4): 413-415. [in Turkish]

Bekleyen A. 2003. A taxonomical study on the zooplankton of Göksu Dam Lake (Diyarbakır). Turk. J. Zool. 27(2):95-100.

Bozkurt A, Göksu MZL, Altun A. 2009. Cladocera and Copepoda fauna of Aslantaş Dam Lake (OsmaniyeTurkey). Journal of FisheriesSciences.com. 3(4):285-297. doi: 10.3153 /jfscom. 2009033

Davidson TA, Sayer CD, Perrow MR, Bramm M, Jeppesen E. 2007. Are the controls of species composition similar for contemporary and sub-fossil cladoceran assemblages? A study of 39 shallow lakes of contrasting trophic status. J Paleolim. 38:117-134. doi: 10.1007/s10933-006-9066-X

DeMott W, Kerfoot C. 1982. Competition among cladocerans: Nature of the interaction between Bosmina and Daphnia. Ecology. 63(6):1949-1966. doi: $10.2307 / 1940132$

Dirican S, Musul H. 2008. Çamlıgöze Baraj Gölü (SivasTürkiye) zooplankton faunası üzerine bir çalışma. SAÜ. Fen Bil Derg. 12 (1):17-21.

Figuerola J, Green AJ. 2002. Dispersal of aquatic organisms by waterbirds: a review of past research and priorities for future studies. Freshwater Biol. 47(3):482-494. doi: 10.1046/j.1365-2427.2002.00829.x

Forró L, Korovchinsky N M, Kotov AA, Petrusek A. 2008. Global diversity of cladocerans (Cladocera; Crustacea) in freshwater. Hydrobiol. 595(1):177-184. doi: 10.1007/s10750-007-9013-5

Frey DG. 1987. The taxonomy and biogeography of the Cladocera. Hydrobiol. 145(1):5-17

Göksu MZL, Çevik F, Bozkurt A, Sarıhan E. 1997. Rotifera and Cladocera fauna of the River Seyhan (The Part Within Borders of Adana City) [in Turkish]. Turk J Zool. 21(4):439-443.

Güher H. 2014. A checklist for zooplankton (Rotifera, Copepoda, Cladocera) of European Turkey inland waters. Ege J Fish Aqua Sci. 31(4):221-225. doi: 10.12714/egejfas. 2014.31.4.08

Güher H. 2002. Cladocera and Copepoda (Crustacea) fauna of Lake Terkos (Durusu). Turk J. Zool. 26(3):283-288.

Güher H. 2000. A faunistic study on the freshwater Cladocera (Crustacea) species in Turkish Thrace (Edirne, Tekirdağ, Kirklareli). Turk J Zool. 24(3):237-243

Güher H. 1999. A taxonomical study on the Cladocera and Copepoda species (Crustacea) of Mert, Erikli, Hamam, Pedina Lakes (İğneada/Kırklareli) [in Turkish]. Turk J Zool. 23, (Ek Sayı 1):47-53.

Güher H, Çolak Ş. 2015. Süloğlu Baraj Gölü’nün (Edirne) zooplankton (Rotifera, Cladocera, Copepoda) faunas1 ve mevsimsel değişimi. Trakya University Journal of Natural Sciences. 16(1):17-24.

Güher H, Kırgız T. 1989. Süloğlu Baraj Gölü ve Korucuköy, Budakdoğanca, Eskikadın Göletlerinin Cladocera ve Copepoda (Crustacea) Türleri. Anadolu Üniv Fen-Edebiyat Derg. 2(1):25-43.
Gündüz E. 1997. A checklist of cladoceran species (Crustacea) living in Turkish inland waters [in Turkish]. Turk J Zool. 21(1):37-45.

Gündüz E. 1991. A taxonomic study on the cladoceran species of Bafra Balıkgölü (Balıkgölü-Uzungöl) [in Turkish]. Turk J Zool. 15:115-134.

Günsel S, Emir Akbulut N. 2012. The investigation of the zooplanktonic organisms of Delice River and its arms in Kizilırmak River basin (Turkey). Hacettepe J. Biol. \& Chem., Special Issue. 40(4):309-316.

Gürel Ö, Saler S. 2015. Zooplankton of Orduzu Pond (Malatya) [in Turkish]. Firat Univ. Journal of Science. 27(1):21-28.

Kattel GR, Mackay A, Battarbee RW. 2006. Variations in patterns of composition and abundance of cladocerans in littoral and open water habitats of Loch Coire Fionnaraich, Scotland. Internat Journ Lakes Riv. $1: 35-50$.

Kaya M, Altındag A, Sezen G. 2012. Seasonal variation of Cladocera fauna of Sultan Marshes and its environment (Central Anatolia, Türkiye). Suleyman Demirel University Journal of Science. 7(2):86-91.

Korinek V. 1987. Revision of three species of the genus Diaphanosoma fischer, 1850, Hydrobiol. 145(1):3545.

Negrea ST. 1983. Fauna Republici Socialiste Romania. Vol.4, 12, Crustacea Cladocera Academia Republic Socialiste Romania, Bucuresti. 1-399.

Özbay H, Kılınç S. 2008. Limnological Studies on the Transboundary Turkish Soda Lake: Lake Aktaş. Fresen Environ Bull. 17(6):722-731.

Pennak RW. 1989. Freshwater invertebrates of the United States, Protozoa to Mollusca. 3rd Ed., John Wiley, New York, 628.

Ryding SO, Rast W. 1989. The control of eutrophication of lakes and reservoirs. Man and the Biosphere 1, Parthenon Press, Carnforth, 314 p.

Saler S, Alış N. 2014. Zooplankton of Hancağız Dam Lake (Gaziantep-Turkey). Journal of Survey in Fisheries Sciences. 1(1):36-45.

Saler S, Arslan S. 2007. Copepoda and Cladocera fauna of TMİ 12 Pond (Elazığ) [in Turkish]. Ege J Fish Aqua Sci. 24(1-2):191-193.

Saler S, İpek N. 2009. Cladocera and Copepoda (Crustacea) fauna of Seli Stream (Elazığ-Turkey). Journal of FisheriesSciences.com. 3(4):318-322. doi: 10.3153/jfscom.2009036

Scourfield DJ, Harding JP. 1966. A key to British species of freshwater Cladocera with notes on their ecology. 3rd ed. Fresh. Biol. Assoc. Sciencific Publication 5.

Smirnov NN. 1974. Fauna of USSR Crustacea Chydoridae. Vol. 1, No 2, English Transl. Israel Prog. Sci. 238-629.

Tellioğlu A, Yılmaztürk Y. 2005. Keban Baraj Gölü Pertek Bölgesi Cladocera ve Copepoda faunası üzerine taksonomik bir çalışma. Journal of Fisheries and Aquatic Sciences. 22(3-4): 431-433.

Tellioğlu A, Şen D. 2001. Seasonal distribution of the Copepoda and Cladocera fauna of Hazar Lake (Elazı̆̆). G.Ü. Gazi Eğitim Fak Derg. 21(2):7-18. 
Temel M. 1996. Riva Deresi zooplanktonu üzerine taksonomik bir çalışma. İstanbul Üniversitesi Su Ürün Fak Derg. 9:1-2

Ustaoğlu MR. 2015. An updated zooplankton biodiversity of Turkish inland waters. LimnoFish. 1(3):151-159. doi: 10.17216/LimnoFish-5000151941

Ustaoğlu MR. 2004. A Check-list for zooplankton of Turkish znland waters. E.U. Journal of Fisheries \& Aquatic Sciences. 21(3-4):191-199.

Ustaoğlu MR, Balık S, Aygen C, Mis D. 2001a. Demirköprü Baraj Gölü Cladocera ve Copepoda
(Crustacea) faunası, XI. Su Ürünleri Sempozyumu; Hatay, 1: 189-197.

Ustaoğlu MR, Balık S, Mis D, Aygen C. 2001b. The Cladocera and Copepoda (Crustacea) fauna of İkizgöl (Bornova-İzmir), Turk J Zool. 25(2):136138.

Yıldız Ş, Özgökçe MS, Özgökçe F, Karaca İ, Polat E. 2010. Zooplankton composition of Van Lake coastline in Turkey. African J Biotech. 9(48):8248-8252. doi: $10.5897 /$ AJB 10.538 